\title{
Indirect Electrochemical Oxidation with Multi Carbon Electrodes for Restaurant Wastewater Treatment
}

\author{
I Dewa Ketut Sastrawidana ${ }^{1 *}$, I Nyoman Sukarta ${ }^{1}$ \\ 1 Department of Chemistry, Faculty of Mathematic and Natural Sciences, Universitas Pendidikan Ganesha \\ Singaraja, Jl. Udayana No. 11, Singaraja, Bali, Indonesia \\ * Corresponding author's e-mail: ketut.sastrawidana@undiksha.ac.id
}

\begin{abstract}
The removal of organic matter from the restaurant wastewater was investigated using the electrochemical oxidation method with multi carbon electrodes in a parallel construction. The degradation process was monitored by the measurement of COD concentration as a function of electrolysis time. The effect of operating parameter conditions on $\mathrm{COD}$ removal were investigated including initial $\mathrm{pH}$, distance between electrodes, and the applied voltage difference. The results showed that the treatment of restaurant wastewater containing $2 \mathrm{~g} / \mathrm{L}$ chloride ion using the electrochemical oxidation technique at the operation conditions characterized by: $\mathrm{pH} 5$, distance between electrode of $10 \mathrm{~cm}$ and applied voltage of $12 \mathrm{~V}$, enabled to obtained COD removal of $92.84 \%$ within 90 min electrolysis time. It is can be concluded that the indirect electrochemical oxidation method with multi carbon electrodes can be used effectively as an alternative technology for reducing COD and may be potentially applied for removal organic pollutants from wastewater at the industrial scale.
\end{abstract}

Keywords: chemical oxygen demand, electrochemical oxidation, multi carbon electrodes, removal efficiency, restaurant wastewater.

\section{INTRODUCTION}

Restaurants are one of the kinds of business that is growing rapidly in Bali province of Indonesia. The growth of restaurant business without respect to the environment may potentially have a negative impact on environmental sustainability due to a wastewater that is produced as a by-product. The restaurant wastewater has a characteristic high content of organic pollutant, which is indicated with the extremely high COD value, TSS and fat, oil and grease (FOG). The main factor contributing to the high content of organic pollutants from restaurant wastewater comes from food preparation materials such as meat, fat, oils, fats and also the use of cleaning agents such as disinfectants, cleaners, and soaps. The high concentrations of soluble organics pollutant in the wastewater have a negative impact to the environment due to the unpleasant odors generated. The organic compound in a restaurant should be properly reduced to acceptable levels through the application of the suitable technology before being discharged into the environment.

Numerous studies have been conducted to remove the organic pollutants from the restaurant wastewater, such as the chemical methods using advanced oxidation process[Krzeminska et al. 2015], electrocoagulation [Chen at al. 2000]; physical methods through ultrafiltration and nanofiltration membranes [Zulaikha et al. 2014]; as well as the biological method with a combined activated sludge-contact aeration system [Chen and Lo. 2006]. Most of the available technologies cannot be applied in industry, especially small industries, due to high operational cost and the requirement of a qualified staff for the operation. On the other hand, the technology for treatment restaurant wastewater has to be simple, inexpensive and operated easily because the profit margins of most restaurants are quite small.

The electrochemical oxidation is a simple, low cost technology but has a high efficiency for the treatment wastewater. This technology is 
relatively new and considered a green technology because it does not add any external chemicals. The electro-oxidation process of pollutants can be formed in two ways: direct oxidation and indirect oxidation. In the direct electro-oxidation, pollutants are oxidized after adsorption on the anode surface without the involvement of others substance [Can 2014]

On the other hand, the indirect electro-oxidation comprises two steps: in the first step, the electrolytes are oxidized at the anode to generate the strong oxidizing agents such as hipochlorous acid, chlorine, hydrogen peroxide. In the second step, these oxidants oxidize the pollutants and convert them into the simpler compounds like carbon dioxide and water [Rajeshwar et al. 1997]. This technology has been tested at laboratory scale and proven to successfully remove pollutants from paper mill effluent [Zayas et al. 2011], landfill leachate [Rada et al. 2013], oil refinery wastewater [Candido et al. 2013], petrochemical effluents [Huitle et al. 2014], pharmaceutical wastewater [Coria et al. 2014], textile wastewater [Subramaniam et al. 2016, Najafpoor et al. 2017] and domestic wastewater [Akarsu et al. 2017].

The aim of the present study is to assess the capability of indirect electrochemical oxidation with multi carbon electrodes in the degradation of restaurant wastewater. The operating parameters involving the initial $\mathrm{pH}$, applied potential, and the distance between electrodes also were investigated.

\section{MATERIALS AND METHODS}

\section{Sample collection}

The restaurant wastewater under study was taken from a Chinese food restaurant in the Buleleng district of Bali, Indonesia. The samples were collected in plastic tanks; COD and initial $\mathrm{pH}$ before treatment were analyzed based on APHA standard methods $5220 \mathrm{C}$ for COD analysis and APHA standard methods $4500 \mathrm{H}$ for $\mathrm{pH}$ measurement. The measurement of Initial $\mathrm{pH}$ and COD value for restaurant wastewater samples were obtained for 6.75 units and $1440 \mathrm{mg} / \mathrm{L}$.

\section{The indirect electrochemical oxidation reactor set up}

The indirect electrochemical oxidation reactor was made for an acrylic sheet with dimension of $60 \times 30 \times 25 \mathrm{~cm}$. Reactor of electrochemical oxidation set up for wastewater treatment was presented in Figure 1.

Degradation experiment of restaurant wastewater was done in an electrochemical oxidation cell reactor with a volume of $2.50 \mathrm{~L}$. The multi carbon (5 anodes and 5 cathodes) with the diameter of $1 \mathrm{~cm}$ and length of $10 \mathrm{~cm}$ was used as the electrode. Multi carbon electrodes were arranged in a parallel system and connected to DC power supply. A stirrer was employed in the reactor to ensure homogeneity of the restaurant wastewater. The investigated operating parameters that influence the COD removal efficiency include initial $\mathrm{pH}$, the distance between electrodes, and applied voltage.

\section{RESULT AND DISCUSSION}

\section{The effect of $\mathrm{pH}$}

The performance of electrochemical oxidation is $\mathrm{pH}$ dependent. In the electro-oxidation process, chloride ion is used as the supporting electrolyte for generating active chlorines $(\mathrm{Cl} 2, \mathrm{HOCl}$ and $\mathrm{ClO}-)$ of different ratio influenced by the $\mathrm{pH}$. The effect of initial $\mathrm{pH}$ on COD removal efficiency of the restaurant wastewater was investigated at dif-

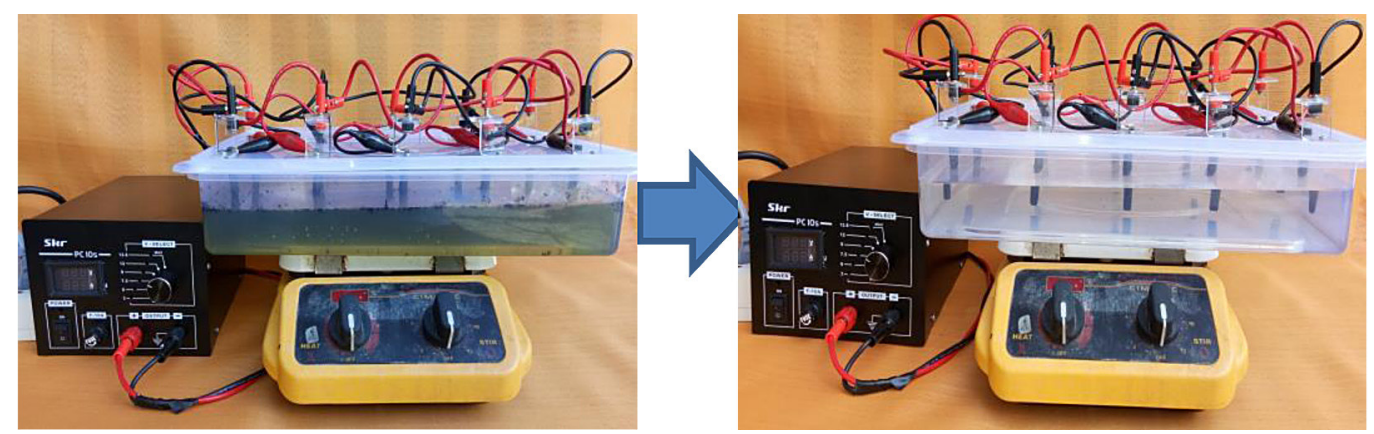

Figure 1. Performance of electrochemical oxidation reactor set up. 
ferent $\mathrm{pH}$ range from 3 to 10 with the use $\mathrm{HCl}$ and $\mathrm{NaOH}$ concentrated to adjust the $\mathrm{pH}$. In the entire experiment, the electrolysis was performed at the voltage of $12 \mathrm{~V}$ with wastewater sample containing $2 \mathrm{~g} / \mathrm{L}$ chloride ion. The percent COD removal in each experiment was monitored as a function of electrolysis duration. The effect of initial $\mathrm{pH}$ on COD removal is presented in Figure 2.

As can be observed from Figure 3, the $\mathrm{pH}$ is an important factor influencing the percent COD removal. The removal efficiency of COD has increased up to the $\mathrm{pH}$ of 5 due to the generation of hypochlorous acid at anode which would be higher at acidic condition. The electrolysis of chloride ion at anode surface generating the active chlorines $\left(\mathrm{Cl}_{2}, \mathrm{HOCl}, \mathrm{ClO}^{-}\right)$which are strong oxidizing agents with standard reduction potential (E'red) value were $1.36 \mathrm{~V}, 1.49 \mathrm{~V}$ and $0.89 \mathrm{~V}$ vs SHE, respectively. On the basis of the standard reduction potential value, the increasing oxidant activity was as followsŁ $\mathrm{HOCl}>\mathrm{Cl}_{2}>\mathrm{ClO}$. The proportion of active chlorines generation is $\mathrm{pH}$ dependent. The electrolysis of chloride ions at low $\mathrm{pH}(\mathrm{pH}<3.3)$ predominantlz produced chlo- rine gas, at the $\mathrm{pH}$ range of $3.3<\mathrm{pH}<7.5$. The active chlorines were present as hypochlorous acid whereas hypochlorite ion was mainly present at $\mathrm{pH}>7.5$ [Azeroual at al. 2017]. In this work, the obtained COD removal efficiency from restaurant wastewater was $92 \%$ at $\mathrm{pH}$ of 5 . The optimum $\mathrm{pH}$ found in this research was slight different from the one obtained by Babu et al. 2012 who reported that the indirect electro-oxidation for COD removal from real polluted water reached $68 \%$ at $\mathrm{pH}$ of 4.5 , with the applied voltage of $16 \mathrm{~V}, \mathrm{NaCl}$ concentration of $0.5 \mathrm{~g} / \mathrm{L}$ within 120 electrolysis time. However, this finding contrasts with Rajkumar et al. 2004, who reported that the COD removal efficiency by electrochemical oxidation treatment was not significantly influenced by the $\mathrm{pH}$ at the range of 3-9. They found that the treatment at the initial $\mathrm{pH}$ of 3-10 within 40 min changed to $\mathrm{pH}$ at range of 7.8-8.3 and then remained constant at $\mathrm{pH}$ of 8.3. A decrease in $\mathrm{pH}$ during the electrochemical oxidation process was also observed in our study. The change in $\mathrm{pH}$ from the initial $\mathrm{pH}$ during electrolysis time was presented in Figure 3.

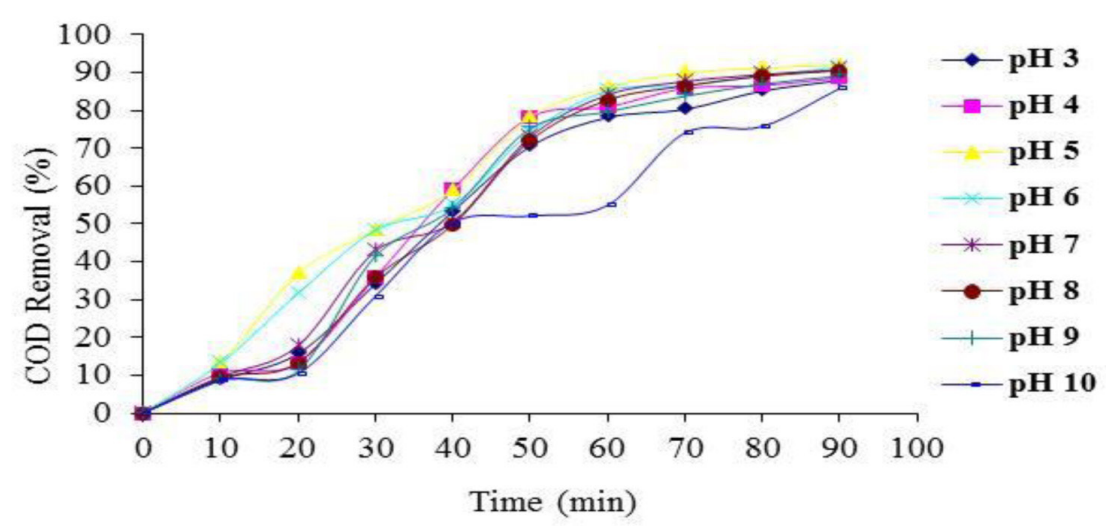

Figure 2. Percent of COD removal efficiency as a function of electrolysis duration at the difference of the initial $\mathrm{pH}$

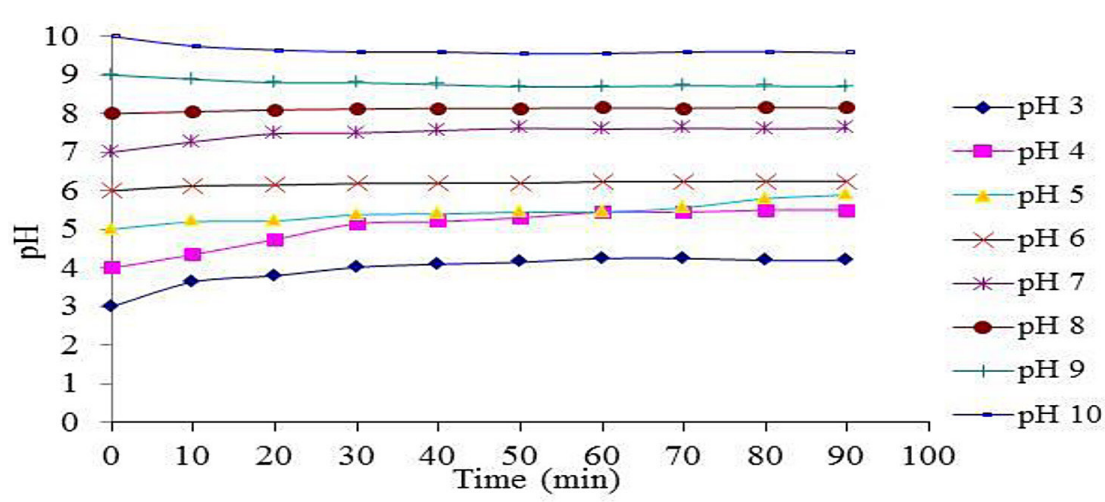

Figure 3. Changing in $\mathrm{pH}$ during the indirect electrochemical oxidation of restaurant wastewater (initial pH 3-10) 
In Figure 3 a change in $\mathrm{pH}$ during the electrooxidation process can be observed; the treatment at range of initial $\mathrm{pH} 3-10$ changed to $4.25-9.56$ after 90 min of electrolysis. Increasing the $\mathrm{pH}$ in each treatment at the initial $\mathrm{pH}$ of 3-8 may be caused by the hydroxide ion, which is generated at the cathode during the electro-oxidation process, whereas the treatment at the initial $\mathrm{pH}$ of 9 and 10 results in a slight decrease due to ion hydrogen which is generated at the anode.

\section{Effect of the distance between electrodes}

In order to investigate the effect of the distance between electrodes on COD removal, the experiment was conducted at varying inter electrode distance. The effect of distance between electrodes on COD removal was illustrated in Figure 4.

Figure 4 clearly shows that COD removal from the restaurant wastewater by means of electrochemical oxidation treatment was influenced by the distance between electrodes. At the electrolysis time range of 10 to $60 \mathrm{~min}$, the COD removal efficiency increased with the decreasing distance between the cathode and anode, while COD removal efficiency was not change significantly at 60 to $90 \mathrm{~min}$ of electrolysis time. This result is in line with Naje et al. 2015, who found that the removal of COD from the textile wastewater was increases with decreasing inter-electrode distance.

\section{Effect of potential difference}

Electrochemical oxidation was conducted using different applied voltage to examine the effect of voltage on COD removal from the restaurant wastewater. The variations of COD removal as a function of electrolysis duration at voltage 9,12 and $15 \mathrm{~V}$ are presented in Figure 5.

Figure 5 shows that for each potential difference, the COD removal efficiency significantly

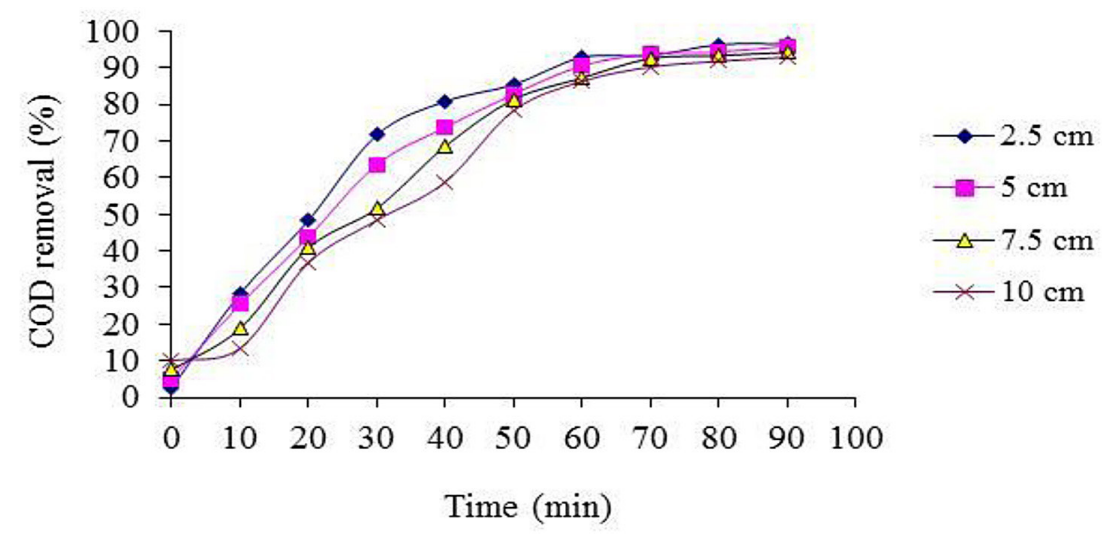

Figure 4. Percent COD removal efficiency as function of electrolysis duration at difference distance between electrodes.

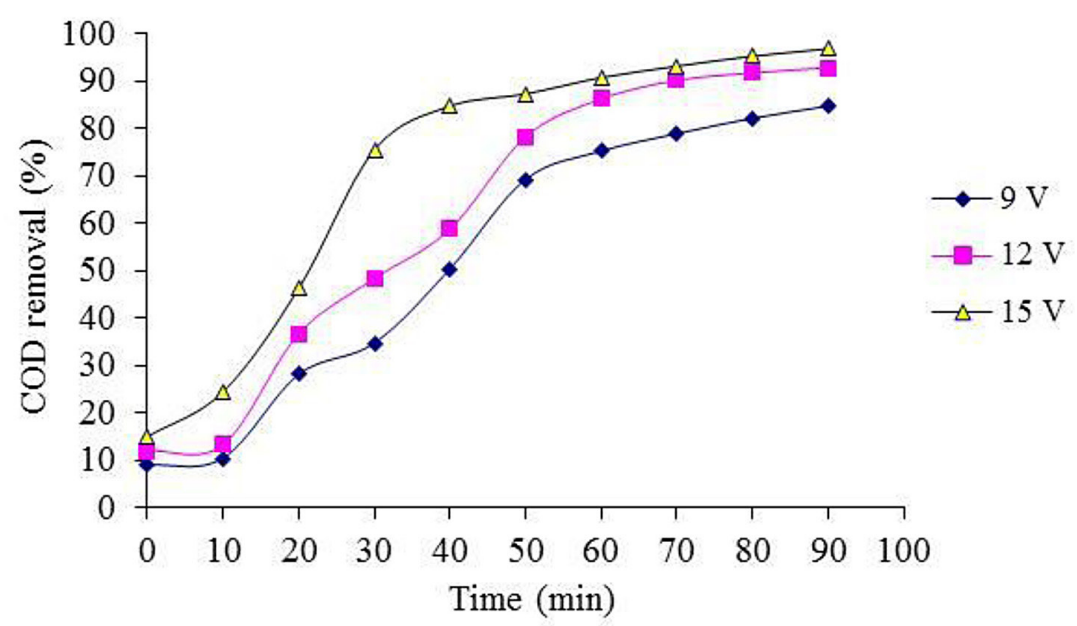

Figure 5. Percent COD removal efficiency as function of electrolysis duration at differet applied voltage. 
increases along with growing electrolysis time. This is due to the production of oxidants (active chlorines) in the solution, where the increasing production of active chlorines such as hypochlorous acid is proportional to the applied voltage. For the applied voltage of 9,12 and $15 \mathrm{~V}$, the maximum obtained COD removal efficiency after $90 \mathrm{~min}$ of electrolysis reached $84.75,92.84$ and $96.83 \%$, respectively. However, the electrooxidation process at a voltage of $15 \mathrm{~V}$ with inters electrodes distance of $10 \mathrm{~cm}$ causes the abrasion of the carbon electrode. Therefore, the optimum of applied voltage is considered to be 12 Volt.

\section{CONCLUSION}

Electrochemical oxidation with multi carbon electrodes was found to be effective in removing the COD from the restaurant wastewater. The degradation process was carried out in electrochemical oxidation reactor with ten carbon electrodes arranged in a parallel system. The results revealed that $92.84 \%$ COD removal from $2.5 \mathrm{~L}$ restaurant wastewater was obtained at the optimum parameters of initial $\mathrm{pH}$ equal to 5 , the distance between electrodes of $10 \mathrm{~cm}$, and applied voltage of 12 volt within $90 \mathrm{~min}$ electrolysis time and $2.0 \mathrm{~g}$ addition of chloride ion per liter of wastewater.

\section{Acknowledgements}

The authors would like to take this opportunity to thanks the Ministry of Research, Technology and Higher Education of Indonesia through the directorate of research and community service for financially supporting this research (Research contract number 215/UN48.15/LT/2017).

\section{REFERENCES}

1. Akarsu C., Ayol A., Taner F. 2017. Treatment of domestic wastewater by using electrochemical process using different metal electrodes. JSM Environ. Sci. Ecol. 5(2), 2-6.

2. Azeroual N., Dani A., Bejjany B., Mellouk H., Digua K. 2017. Effect of the mixing velocity and the active chlorine concentration in analyte on the indirect electrochemical oxidation of the Acid Red 35 dye. J. Mater. Environ. Sci. 8(8), 2769.

3. Babu S.A., Raja S., Sibi S., Neeraja P. 2012. Decolorization of synthetic and polluted water by indirect electrochemical oxidation process. Poll. Res. 31(1), 45-49.
4. Can O.T. 2014. COD removal from fruit-juice production wastewater by electrooxidation electrocoagulation and electro-fenton processes. Desalination and Water Treatment. 52, 65-73.

5. Candido L., Ponciano Gomes J.A.C., Jambo H.C.M. 2013. Electrochemical treatment of oil refinery wastewater for NH3-N and COD removal. Int. J. Electrochem. Sci. 8, 9187-9200.

6. Chen X., Chen G., Yue P.L. 2000. Separation of pollutants from restaurant wastewater by Electrocoagulation. Separation and Purification Tech. 19, 65-76.

7. Chen C.K., Lo S.L. 2006. Treating restaurant wastewater using a combined activated sludge-contact aeration system. J. Environ. Biol. 27(2), 167-183.

8. Coria G., Nava J.L., Carreno G., 2014. Electrooxidation of diclofenac in synthetic pharmaceutical wastewater using an electrochemical reactor equipped with boron doped diamond electrode. J. Mex. Chem. Soc. 58(3), 303-308.

9. Huitle C.A.M., de Moura D.C., da Silva D.R. 2014. Applicability of electrochemical oxidation process to the treatment of petrochemical effluents. Chem. Eng. Transactions. 21, 373-378.

10. Krzeminska D., Neczaj E., Borowski G. 2015. Advanced oxidation processes for food industrial wastewater decontamination. J. Ecol. Eng. 16(2), 61-71

11. Najafpoor A.A., Davoudi M., Salmani E.R. 2017. Decolorization of synthetic textile wastewater using electrochemical cell divided by cellulosic separator. J. Environ. Health Sci. Eng. 15(11), 2-11.

12. Naje A.S., Chelliapan S., Zakaria Z., Abbas S. 2015. Enhancement of electrocoagulation process for the treatment of textile wastewater under combined electrical connections using titanium plates. Int. J. Electrochem. Sci. 10, 4495-4512.

13. Rada E.C., Istrate I.A., Ragazzi M., Andreottola G., Torretta V. 2013. Analysis of electro oxidation suitability for landfill leachate treatment through an experimental study. Sustainability. 5, 3960-3975.

14. Rajeshwar K., Ibanez J.G. 1997. Environmental electrochemistry; Fundamentals and applications in pollution abatement. Academic Press, Inc. California.

15. Rajkumar D., Kim J.G., Kim K.K. 2004. Study on electrochemical oxidation of catechol in chloride medium for wastewater treatment application. Environ. Eng. Res. 9(6), 279-287.

16. Subramaniam D., Halim A.A., Hanafiah M.M. 2016. Performance of electrochemical oxidation in treating textile industry wastewater by graphite electrode. Nat. Environ. Pollut. Tech. 15(3), 1021-1026.

17. Zayas T., Picazo M., Salgado L. 2011. Removal of organic matter from paper mill effluent by electrochemical oxidation. J. Water Resource. Prot. 3, 32-40.

18. Zulaikha A., Lau W.J., Ismail A.F., Jaafar J. 2014. Treatment of restaurant wastewater using ultrafiltration and nanofiltration membranes. J.Water Process Eng. 2, 58-62 